\section{Innovative Use of Locally Produced Inputs to Improve Plant Growth, Crop Quality, and Grower Profitability in Hawai'i}

\author{
Theodore J.K. Radovich ${ }^{1,6}$, Archana $\operatorname{Pant}^{1}$, Ian Gurr ${ }^{2}$, \\ Ngyuen V. Hue ${ }^{1}$, Jari Sugano ${ }^{3}$, Brent Sipes ${ }^{3}$, Norman Arancon ${ }^{4}$, \\ Clyde Tamaru $^{5}$, Bradley K. Fox ${ }^{5}$, Kent D. Kobayashi ${ }^{1}$, and \\ Robert Paull ${ }^{1}$
}

\begin{abstract}
ADDITIONAL INDEX WORDs. tankage, algae, seaweed, compost, vermicompost, compost tea, seedling production, sustainable agriculture

SUMMARY. Reducing grower reliance on off-island inputs to promote plant nutrition was identified by industry as a high priority in efforts to improve agricultural sustainability in Hawai'i. A variety of knowledge gaps exist that prevent producers from using locally produced amendments in the fertility program. This study will focus on recent transdisciplinary efforts at the University of Hawai'i to improve understanding of factors that affect variability in the quality, application, efficacy, and cost-effectiveness of locally produced composts, vermicomposts, rendered animal products, and algae in Hawai'i. A series of greenhouse, experiment station, and on-farm trials have supported several conclusions, including 1) aqueous extracts of vermicomposts and high-quality, farmer-produced thermophilic composts can effectively improve crop growth and reduce costs associated with the use of these inputs; 2) replacement of peat and other imports with local materials in vegetable seedling production have the potential to improve seedling vigor and reduce costs in the long term; 3) commercially produced rendered meat products, alone and in combination with commercial composts, are a valuable local source of nitrogen $(\mathrm{N})$; and 4 ) invasive algae from coral reef remediation may provide a significant source of potassium $(K)$ in the near term, but $K$ content of algae is highly dependent on species and location of growth.
\end{abstract}

S oils generally have insufficient amount of nutrients, such as $\mathrm{N}$, phosphorus $(\mathrm{P})$, and $\mathrm{K}$ for crops to reach the maximum yield. Therefore, farmers apply soil amendments,

This paper was part of the workshop "Nutrient and Water Management Practices for Improving Crop Growth, Yield, and Quality" held 26 Sept. 2011 at the ASHS Conference, Waikoloa, HI, and sponsored by the Plant Nutrient Management (PNM) Working Group.

Research support provided for by the USDA-TSTAR, -WSARE, and -OREI programs.

We gratefully acknowledge the assistance of the field staff at the Waimanalo and Poamoho Research Stations and the Magoon greenhouse facility.

${ }^{1}$ Department of Tropical Plant and Soil Science, University of Hawai'i Manoa, 3190 Maile Way, Honolulu, HI 96822-2279

${ }^{2}$ Land Grant Program, American Samoa Community College, P.O. Box 2609 Pago Pago, AS 96799

${ }^{3}$ Department of Plant and Environmental Protection Science, University of Hawai'i Manoa, 3050 Maile Way, Honolulu, HI 96822-2279

${ }^{4}$ College of Agriculture, Forestry and Natural Resource Management, University of Hawai'i Hilo, 200 W. Kawili Street, Hilo, HI 96720-4091

${ }^{5}$ Department of Natural Resources and Environmental Management, University of Hawai'i Manoa, 1910 East-West Road, Honolulu, HI 96822-2279

${ }^{6}$ Corresponding author. E-mail: theodore@hawaii.edu. including commercial or organic fertilizers that are rich in nutrients to ensure increased crop productivity (Abbasi and Adams, 2000). The addition of organic matter to the soil may also improve soil structure, aeration, soil water holding capacity, and water infiltration (Fulhage, 2000; Yu-hong et al., 2005) and is considered an agronomically feasible and economically viable manure and other organic waste disposal option (Kuo et al., 2004).

Improved food security in the Pacific islands requires that a costeffective, stable source of local fertilizer be available to growers. Costs of imported fertilizers increased from $\$ 300$ to $\$ 1000$ per ton between 2006 and 2008, which increased the demand for local organic fertilizers to keep local producers competitive. Compost, meat meal, and seaweeds are good sources of nutrients, although information about their performance in Hawai'i soils and conditions is lacking, and specific challenges in using each of these products exists. This article describes recent efforts in Hawai'i to address these challenges and gaps in knowledge.

\section{Compost}

Composts used by commercial agricultural producers in Hawai'i can be of variable quality (Table 1 ). Vermicomposts and intensively managed thermophilic composts are considered valuable for plant growth promotion in the short term. Vermicomposts generally have finer structure, contain higher nutrients, and show better microbial activity than other types of compost. A comparison of the biological community of thermophilic composts and vermicomposts has demonstrated that vermicomposts produced a greater diversity, population size, and functional diversity of microorganisms (Devi et al., 2009; Vivas et al., 2009). Greater biomass and diversity of microorganisms associated with vermicompost results in enhanced plant growth because of the production of plant growth promoting substances, disease and pest suppression, improved physical and chemical properties, and increased nutrient content and availability (Arancon et al., 2004). This has generally been found to be true in Hawai'i as well (Gurr, 2011; Hue and Sobieszczy, 1999). However, locally produced on-farm thermophilic composts have been identified as comparable to local vermicomposts in plant nutrient content and plant growth promotion (Table 1).

\begin{tabular}{llll}
\hline $\begin{array}{l}\text { Units } \\
\begin{array}{l}\text { To convert U.S. to SI, } \\
\text { multiply by }\end{array}\end{array}$ & U.S. unit & SI unit & $\begin{array}{l}\text { To convert SI to U.S., } \\
\text { multiply by }\end{array}$ \\
\hline 0.0283 & $\mathrm{ft}^{3}$ & $\mathrm{~m}^{3}$ & 35.3147 \\
2.54 & inch(es) & $\mathrm{cm}$ & 0.3937 \\
0.4536 & $\mathrm{lb}$ & $\mathrm{kg}$ & 2.2046 \\
1.1209 & $\mathrm{lb} / \mathrm{acre}$ & $\mathrm{kg} \cdot \mathrm{ha}^{-1}$ & 0.8922 \\
28.3495 & $\mathrm{oz}$ & $\mathrm{g}$ & 0.0353 \\
1 & $\mathrm{ppm}$ & $\mathrm{mg} \cdot \mathrm{kg}^{-1}$ & 1 \\
0.9072 & ton(s) & $\mathrm{Mg}$ & 1.1023 \\
2.2417 & $\operatorname{ton}(\mathrm{s}) / \mathrm{acre}$ & $\mathrm{Mg} \cdot \mathrm{ha}^{-1}$ & 0.4461
\end{tabular}


Table 1. Content of selected nutrients in vermicompost and thermophilic compost available in Hawai'i. Analyses were conducted on 157 samples 2006-11 (T.J.K. Radovich, N.V. Hue and A. Pant, unpublished data).

\begin{tabular}{|c|c|c|c|c|c|c|c|c|c|}
\hline \multirow[b]{2}{*}{ Method } & \multirow[b]{2}{*}{ Feedstock } & \multirow[b]{2}{*}{$\begin{array}{c}\text { Samples } \\
\text { (no.) }\end{array}$} & & \multicolumn{6}{|c|}{ Nutrient conten $\mathrm{t}^{\mathrm{z}}$} \\
\hline & & & & C:N (\%) & $\mathbf{N}(\%)$ & $\mathrm{P}(\%)$ & K (\%) & $\begin{array}{c}\mathrm{NO}_{3}-\mathrm{N} \\
\left(\mathrm{mg} \cdot \mathrm{kg}^{-1}\right)\end{array}$ & $\begin{array}{c}\mathrm{NH}_{4}-\mathrm{N} \\
\left(\mathrm{mg} \cdot \mathrm{kg}^{-1}\right)\end{array}$ \\
\hline \multirow[t]{4}{*}{ Vermicompost } & Food waste & 42 & Mean & $12: 1$ & 2.11 & 0.79 & 1.47 & 1672.2 & 141 \\
\hline & & & Range & $5: 1-25: 1$ & $0.89-4.59$ & $0.06-2.06$ & $0.06-4.83$ & $267-2986$ & $2-969$ \\
\hline & & & CV $(\%)^{\mathrm{y}}$ & 27 & 39 & 70 & 98 & 93 & 164 \\
\hline & Manure & 59 & Mean & $14: 1$ & 1.67 & 3.04 & 0.55 & 1988.88 & 185 \\
\hline \multirow[t]{5}{*}{ Thermal } & Green-wastes & 28 & Mean & $21: 1$ & 1.28 & 0.45 & 0.77 & 634 & 21 \\
\hline & & & Range & $8: 1-40: 1$ & $0.67-2.72$ & $0.14-0.92$ & $0.21-1.12$ & $35-1913$ & $0-175$ \\
\hline & & & $\mathrm{CV}(\%)$ & 42 & 37 & 47 & 30 & 80 & 369 \\
\hline & Manure and & 28 & Mean & 19:1 & 1.77 & 1.69 & 1.68 & 3834 & 243 \\
\hline & & & Range & $10: 1-26: 1$ & $0.61-3.01$ & $0.21-3.78$ & $0.48-3.13$ & $60-8625$ & $26-1813$ \\
\hline
\end{tabular}

${ }^{\mathrm{z}} \mathrm{C}: \mathrm{N}=$ carbon:nitrogen ratio, $\mathrm{N}=$ nitrogen, $\mathrm{P}=$ phosphorus, $\mathrm{K}=$ potassium, $\mathrm{NO}_{3}-\mathrm{N}=$ nitrate $-\mathrm{N}, \mathrm{NH} \mathrm{H}_{4}-\mathrm{N}=\operatorname{ammonium}-\mathrm{N} ; \mathrm{l} \mathrm{mg} \cdot \mathrm{kg}^{-1}=\mathrm{l}$ ppm.

${ }^{y}$ Coefficient of variation is an indicator of the variation within the compost samples for that nutrient.

High-quality composts can be prohibitively expensive (e.g., \$3 per pound) because of higher labor and water requirements, as well as lower compost yields and the inability to capture economies of scale by small compost producers. Innovative use of smaller quantities of high-quality compost can improve cost-effectiveness and still provide benefits to plants. Two strategies that have seen limited early adoption by innovative growers to provide cost-effective benefits from these high-value local inputs in small-scale commercial systems in the state include 1) using aqueous compost extracts or compost tea to extend applications over a larger area and 2) incorporating composts into growth media to target applications directly to the seedling and replace imported materials. Recent work to evaluate these practices is described.

\section{Compost tea}

Water-based extracts of compost or compost tea have a relatively long history in agriculture. This is not surprising since they are simple to make by soaking compost in water and agitating by stirring, aeration, or other methods. Scientific investigations of claims of the benefits of compost tea are fairly recent. Study results have been variable, but there is considerable evidence that compost teas can improve plant production by decreasing disease incidence, improving plant nutrient status, and generally promoting plant growth (Arancon et al., 2007;
Hargreaves et al., 2008; Ingham, 2005; Weltzien, 1990).

In the last five to 10 years, there was a dramatic increase in the interest and use of compost tea, particularly by new growers. Several growers and landscape managers are early adopters of compost tea in Hawai'i (Radovich and Arancon, 2012). These growers vary in the types of equipment they use to extract the compost, the ratio of water to compost, and the type of compost. There are several assumptions that many growers make when extracting compost, including 1) biological activity in the compost tea should be high at the time of application, 2) aeration and additives (e.g., sugars, seaweed extracts, humic acid, etc.) improve the biological quality and efficacy of tea, and 3 ) vermicompost is the best material for producing compost tea.

The above assumptions were not systematically tested in Hawai'i until recently. In 2007, the Western Region Sustainable Agriculture Research and Education program of the U.S. Department of Agriculture awarded funds to the University of Hawai'i at Mānoa and the industry partners and collaborating growers to help clarify the unknowns regarding compost tea. Early experiments indicated that spraying the plant canopy alone did not significantly affect yield (unpublished data). Multiple studies subsequently conducted in the field, greenhouse, and laboratory have demonstrated that application of compost tea to the root zone can significantly increase plant yield and root growth in multiple soil types and media (Fig. 1) using extraction ratios of 10:1-100:1 (water:compost) by volume (Pant, 2011; Pant et al., 2009, 2011, 2012). These studies also found that the effect on plant growth and quality was closely related to plant $\mathrm{N}$ status; soil biological activity was increased with application of compost tea to soil; variability in plant growth response to extracts from different composts were largely explained by variability in nitrate $\left(\mathrm{NO}_{3}-\mathrm{N}\right)$, gibberellic acid $\left(\mathrm{GA}_{4}\right)$, and humic acid concentrations in the teas; exogenous $\mathrm{GA}_{4}$ stimulated seedling root growth when applied in concentrations found in compost teas; aeration was not required for, but did accelerate, the production of effective teas; and no significant relationship was found between plant growth and total biological activity in the compost tea.

Based on these findings, three primary mechanisms have been proposed for increased yields and improved nutrient status of plants receiving compost tea: 1) extracts directly contribute plant available nutrients, 2) extracts increase soil biological activity consequently improving nutrient mineralization and plant availability, 3) extracts increase nutrient interception via enhanced root growth. The data have also been used to develop growers' recommendations in a handbook for compost tea use in Hawai'i (Radovich and Arancon, 2012). 

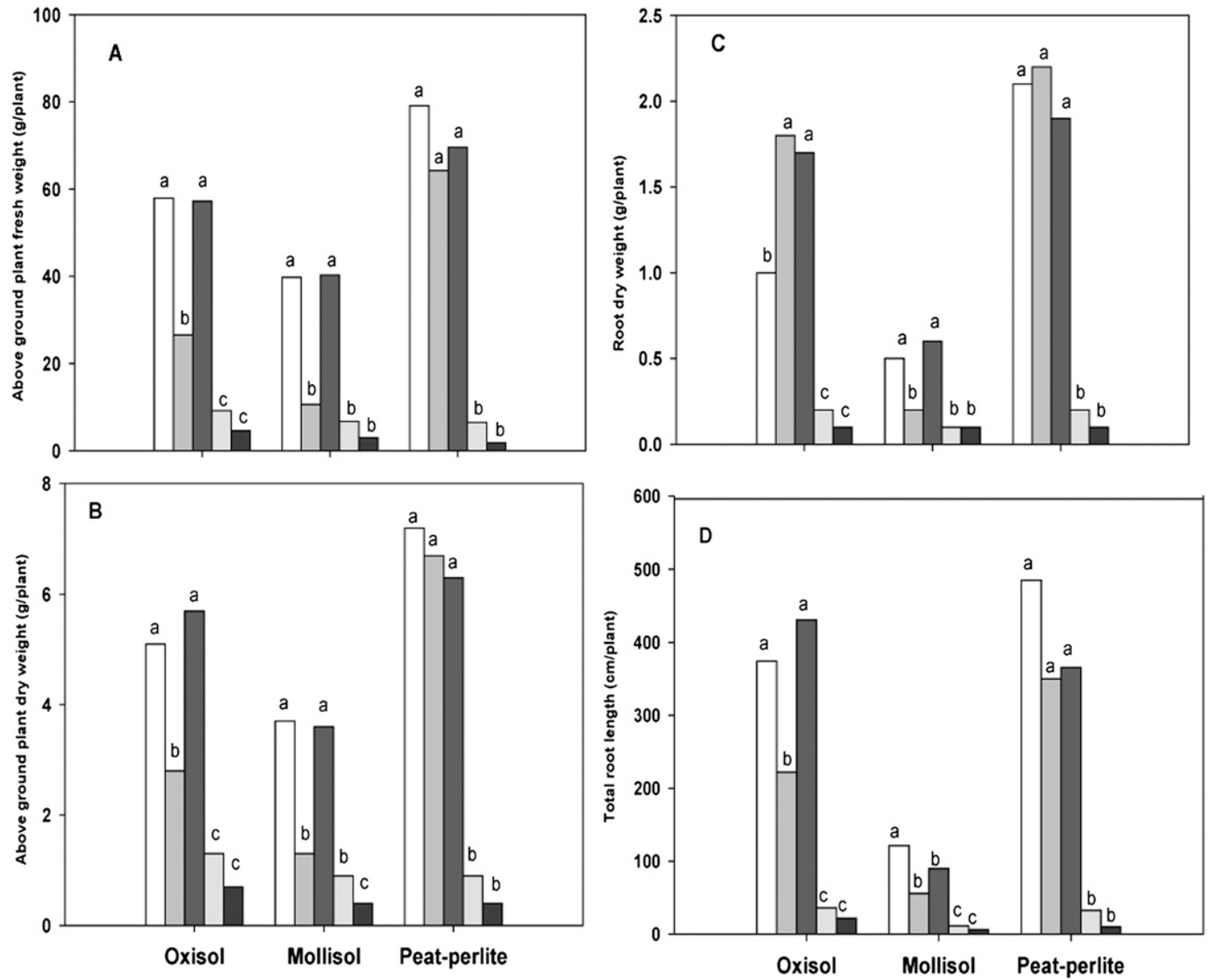

Fig. 1. Extract effect on (A) aboveground plant fresh weight, (B) aboveground plant dry weight, (C) root dry weight, and (D) total root length of pak choi under compost fertilization $(n=4)$. Means followed by the same letter are not significantly different $(P<0.05)$ within each growth medium; ACT = aerated vermicompost tea, ACTME = aerated vermicompost tea with microbial enhancer, NCT $=$ nonaerated vermicompost tea, $\mathrm{MNS}=$ mineral nutrient solution, Control $=$ water; $1 \mathrm{~g}=0.0353 \mathrm{oz}, 1 \mathrm{~cm}=$ 0.3937 inch (adapted from Pant et al., 2011).

\section{Compost in seedling media}

Vegetable seedling production in Hawai'i relies heavily in sphagnum peatmoss-based growth media. Though peat has many of the properties required for quality vegetable seedling production, it must be transported long distances to Hawai'i. To reduce reliance on imported peat, substitution of $20 \%$ to $30 \%$ by volume with renewable media components, particularly locally produced thermophilic composts, has been promoted (Uchida et al., 1979; Yogi et al., 1997). However, vermicomposts had not yet been adequately evaluated for media components in the state. Other studies demonstrate that vermicompost increases seed germination, disease tolerance, plant growth, and crop yield (Arancon et al., 2004; Atiyeh et al., 2001; Diaz-Perez and Camacho-Ferre, 2010; Suthar, 2010; Zaller, 2007). For example,
Arancon et al. (2006) found that vermicomposting results in increased levels of ammonium $\left(\mathrm{NH}_{4}{ }^{+}-\mathrm{N}\right)$, $\mathrm{NO}_{3}{ }^{-} \mathrm{N}$, and orthophosphate, which improved plant growth and yield. Other researches suggest that humic substances present in vermicompost cause increased seed germination (Lazcano et al., 2010) and enhanced plant growth (Arancon et al., 2003). Together, these results suggest that substitution of peat-based media with vermicompost can improve not only seedling growth but also yield following transplanting into the field.

Vermicomposts, alone and in combination with other locally produced media components, were evaluated as alternatives to peat over the course of one field and four greenhouse trials using eggplant (Solanum melongena) and pak choi (Brassica rapa Chinensis group) (Gurr, 2011). The total pore space, water holding capacity, and air-filled porosity were similar for peat and vermicompost used in the study. In early trials, amending peat, coconut coir, and thermophilic compost with vermicompost increased seedling shoot tissue $\mathrm{N}$ content and seedling shoot dry weight, with the greatest shoot dry weights obtained from $100 \%$ vermicompost. Unfortunately, the costs of local vermicompost can exceed $\$ 90 / \mathrm{ft}^{3}$. Subsequent trials combining inexpensive, locally produced media components, particularly thermophilic composts and tankage, generated affordable media that produced eggplant seedlings of comparable quality to those produced with peat and soluble fertilizer, and exceeded the quality of seedlings produced with $100 \%$ vermicompost (Gurr, 2011). These media are currently being evaluated in commercial production systems in the state. 


\section{Tankage}

Tankage is the solid by-product of animal waste rendering. The nutrient content of tankage will vary with feedstock, but the product in Hawai'i has fairly consistently been analyzed at $8.0 \%, 2.5 \%, 0.75 \%$, and $5.0 \% \mathrm{~N}, \mathrm{P}$, $\mathrm{K}$, and calcium, respectively with a carbon:N ratio of 5:1 (Arakaki, 2008; Garcia and Rosentrater, 2008). Similar numbers have been observed in material from American Samoa (T.J.K. Radovich and I. Gurr, unpublished data). The relatively low $\mathrm{P}$ content is because the Hawai'i material is derived primarily from fish scraps and waste meat from food distributors (the Samoan material is exclusively fish scraps from canning operations), and contains low bone content. Often called meat and bone meal, tankage is a valuable agricultural input (Blatt, 1991; Mondini et al., 2008) used as fertilizer in Hawai'i for at least 20 years (Valenzuela et al., 2001).

The primary agricultural use of tankage is as a supplemental $\mathrm{N}$ source (Jeng et al., 2006), especially for, but not limited to, certified organic growers. The material has been recognized as National Organic Program compliant by certifying agencies in the state. Demand for the product continues to grow proportionally to the rising cost of synthetic fertilizer, and the need for recommended application rates to guide growers is increasingly apparent. Research has identified application rates of 2-5 Mg.ha $\mathrm{h}^{-1}$ as adequate for plant growth, with rates of $9 \mathrm{Mg} \cdot \mathrm{ha}^{-1}$ suppressing yields [Arakaki, 2008; Valenzuela et al., 2001 (Fig. 2)]. Preliminary recommendations for most short-cycle vegetable crops are $1800-3500 \mathrm{~kg} \cdot \mathrm{ha}^{-1}$ per crop cycle. Residual $\mathrm{N}$ availability has been observed in subsequent crop cycles at rates exceeding $2.27 \mathrm{Mg} \cdot \mathrm{ha}^{-1}$, and frequent use of the material should be accompanied by regular soil testing to avoid over applying $\mathrm{N}$. Ongoing research work is focused on narrowing the range of recommended rates for specific crops and soil types in Hawai'i. Currently, there is a single plant in the state producing tankage at an approximate rate of $55 \mathrm{Mg}$ per month. Increased production will be necessary if tankage is to serve as a significant, sustained source of agricultural $\mathrm{N}$ in Hawai'i.

\section{Algae}

Invasive algae are currently available in large quantities in some parts of the state where reef remediation efforts are ongoing. Innovative growers have been collecting the material from conservation groups and applying it to fields either directly or after composting. The algae are expected to be an important source of $\mathrm{K}$ and other plant nutrients; however, nutrient content depends heavily on species and may also vary with location. In Maunalua bay on O'ahu, the dominant species, Avrainvillea amadelpha, was very low in $\mathrm{K}$ compared with other species also collected in the area in smaller quantity (Table 2). Invasive species high in K (e.g., Gracilaria salicornia, Kappaphycus alvarezii, and $K$. striatum) do infest many locations across the state and have been routinely applied in high rainfall areas without apparent problems associated with salinity. Rates of application vary significantly across farms. Estimates for application rates of high$\mathrm{K}$ species at one farm in a high-rainfall area to long-term crops taro (Colocasia esculenta) and sweetpotato (Ipomoea batatas) are $5.7 \mathrm{Mg} \cdot \mathrm{ha}^{-1}$ on a dry weight basis. At an algae concentration of $10 \% \mathrm{~K}$ dry weight, this is equivalent to $570 \mathrm{~kg} \cdot \mathrm{ha}^{-1}$ of $\mathrm{K}$.

Public and private partnerships have been formed to achieve multiple objectives identified as requisite to optimizing invasive algae as an agricultural input (Franklin, 2010). These objectives include elucidating location and species effects on mineral nutrient concentrations, estimating acceptable loading rates for salts and metals from the algal applications for selected Hawaiian soils, and optimizing processing procedures for salt reduction and maximum nutrient content.

\section{Conclusion}

As commercial fertilizer costs increase with oil prices, many food producers in the Pacific region have become interested in locally available

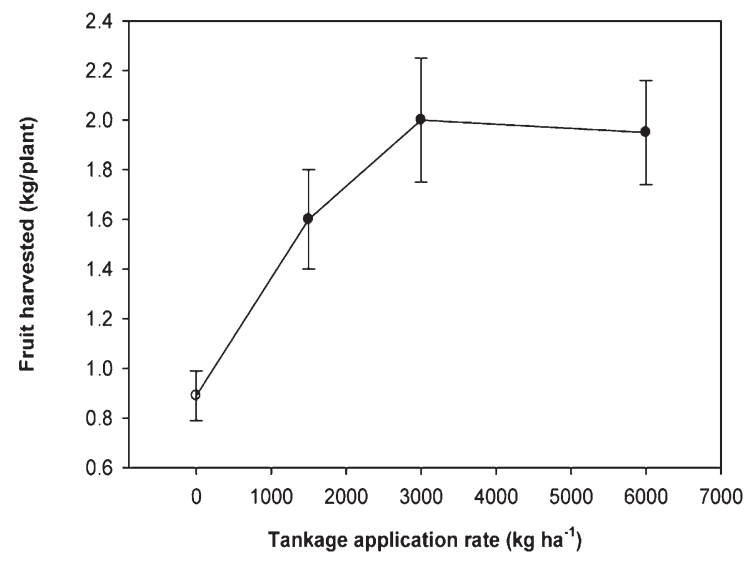

Fig. 2. Eggplant fruit yield as affected by tankage application rate in field trial conducted at the University of Hawai'i Waimanalo Research Station in Aug. to Dec. 2010. Plotted points are means of four replications and error bars represent the SE; $1 \mathrm{~kg} \cdot \mathrm{ha}^{-1}=0.8922 \mathrm{lb} /$ acre, $1 \mathrm{~kg}=2.2046 \mathrm{lb}$.

Table 2. Nutrient analysis of algae. Note the significant variability in potassium among species. Values are means of four to ten samples.

\begin{tabular}{lccccccc}
\hline & \multicolumn{1}{c}{ Nitrogen } & \multicolumn{1}{c}{ Carbon } & Phosphorus & Potassium & Calcium & Magnesium & Sodium \\
\cline { 2 - 7 } Algae species & \multicolumn{5}{c}{ [mean \pm SE (\%)] } \\
\hline Avrainvillea amadelpha & $0.9 \pm 0.1$ & $16.7 \pm 0.9$ & $0.06 \pm 0.001$ & $0.2 \pm 0.04$ & $16.9 \pm 1.7$ & $1.5 \pm 0.1$ & $2.0 \pm 0.2$ \\
Acanthophora spicifera & $1.14 \pm 0.17$ & $20.0 \pm 01.5$ & $0.04 \pm 0.004$ & $4.2 \pm 1.9$ & $8.8 \pm 1.6$ & $1.5 \pm 0.07$ & $3.2 \pm 0.1$ \\
Gracilaria salicornia & $0.58 \pm 0.13$ & $15.7 \pm 2.6$ & $0.05 \pm 0.004$ & $10.4 \pm 02.6$ & $6.1 \pm 1.8$ & $1.1 \pm 0.2$ & $3.0 \pm 0.2$ \\
\hline
\end{tabular}


by-products that are suitable for use as agricultural inputs to improve crop health and productivity. Innovative growers have identified composts, tankage, and invasive algae as promising inputs to address these challenges. Work at the University of Hawai'i has confirmed the potential of these inputs to improve the sustainability of local operation, once key bottlenecks and challenges have been removed. Cooperative extension specialists and agents will continue to engage innovators and early adaptors to facilitate responsible mainstream adoption of optimized strategies that use these and other local inputs in ways most beneficial to our growers.

\section{Literature cited}

Abbasi, M.K. and W.A. Adams. 2000. Estimation of simultaneous nitrification and denitrification in grassland soil associated with urea- $\mathrm{N}$ using $15 \mathrm{~N}$ and nitrification inhibitor. Biol. Fertil. Soils 31:38-44.

Arakaki, A. 2008. Response of corn and bean seedlings to pre-plant applications of Island Commodities Inc. bone meal. 10 Aug. 2012. <http://www.ctahr.hawaii. edu/organic/downloads/Effect $\% 20 \mathrm{of} \%$ 20Bone\%20Meal\%20Soil\%20Amendment\% 20on\%20Corn\%20and\%20Bean\%20Seedlings. pdfs.

Arancon, N.Q., C.A. Edwards, R. Atiyeh, and J.D. Metzger. 2004. Effects of vermicomposts produced from food waste on the growth and yields of greenhouse peppers. Bioresour Technol. 93:139-144.

Arancon, N.Q., C.A. Edwards, R. Dick, and L. Dick. 2007. Vermicompost tea production and plant growth impacts. Biocycle 48(11):51-52.

Arancon, N.Q., C.A. Edwards, S. Lee, and R. Byrne. 2006. Effects of humic acids from vermicomposts on plant growth. Eur. J. Soil Biol. 45:S65-S69.

Arancon, N.Q., S. Lee, C.A. Edwards, and R.M. Atiyeh. 2003. Effects of humic acids and aqueous extracts derived from cattle, food and paper-waste vermicomposts on growth of greenhouse plants. Pedobiologia (Jena) 47:721-744.

Atiyeh, R.M., C.A. Edwards, S. Subler, and J.D. Metzger. 2001. Pig manure vermicompost as a component of a horticultural bedding plant medium: Effects on physicochemical properties and plant growth. Bioresour. Technol. 78:11-20.

Blatt, C.R. 1991. Comparison of several organic amendments with a chemical fertilizer for vegetable production. Scientia Hort. 47:177-191.
Devi, S.H., K. Vijayalaksmi, K.P. Jyotsna, S.K. Shaheen, K. Jyothi, and M.S. Rani. 2009. Comparative assessment in enzyme activities and microbial populations during normal and vermicomposting. J. Environ. Biol. 30:1013-1017.

Diaz-Perez, M. and F. Camacho-Ferre. 2010. Effect of composts in substrates on the growth of tomato transplants. HortTechnology 20:368-376.

Franklin, K. 2010. What do you do with 829 tons of algae? 10 Aug. 2012. <http:// www.ctahr.hawaii.edu/sustainag/news/ articles/V5-Malama-limu.pdf>.

Garcia, R.A. and K.A. Rosentrater. 2008. Concentration of key elements in North American meat \& bone meal. Biomass Bioenergy 32:887-891.

Gurr, I. 2011. Evaluating vermicompost and rendered meat products as local media components in vegetable seedling production. Univ. Hawai'i, Mānoa, MS Thesis.

Hargreaves, J., M.S. Adl, P.R. Warman, and H.P.V. Rupasinghe. 2008. The effects of organic amendments on mineral element uptake and fruit quality of raspberries. Plant Soil 308:213-226.

Hue, N.V. and B.A. Sobieszczy. 1999. Nutritional values of some biowastes as soil amendments. Compost Sci. Util. 7: 34-41.

Ingham, E.R. 2005. Compost tea: Promises and practicalities. The IPM Practitioner: The newsletter of integrated pest management $1-5$.

Jeng, A.S., T.K. Haraldsen, A. Gronlund, and P.A. Pedersen. 2006. Meat and bone meal as nitrogen and phosphorus fertilizer to cereals and rye grass. Nutr. Cycl. Agroecosyst. 76:183-191.

Kuo, S., M.E. Ortiz-Escobar, N.V. Hue, R.L. Hummel, and S.G. Pandalai. 2004. Composting and compost utilization for agronomic and container crops. Recent Res Dev. Environ. Biol. 1:451-513.

Lazcano, C., L. Sampedro, R. Zas, and J. Domínguez. 2010. Vermicompost enhances germination of the maritime pine (Pinus pinaster Ait.). New Forests 39: 387-400.

Mondini, C., M.L. Cayuela, T. Sinicco, M.A. Sánchez-Monedero, E. Bertolone, and L. Bardi. 2008. Soil application of meat and bone meal: Short-term effects on mineralization dynamics and soil biochemical and microbiological properties. Soil Biol. Biochem. 40:462-474.

Pant, A. 2011. Vermicompost tea: Effects on pak choi (Brassica rapa cr. Bonsai, Chinensis group) growth yield, phytonutrient content and soil biological properties. Univ. Hawai'i, Mānoa, PhD Diss.

Pant, A., T.J.K. Radovich, N.V. Hue, and N.Q. Arancon. 2011. Effects of vermicompost tea (aqueous extract) on pakchoi yield, quality and soil biological properties. Compost Sci. Util. 19:279292.

Pant, A., T.J.K. Radovich, N.V. Hue, and N.Q. Arancon. 2012. Pak choi (Brassica rapa, Chinensis group) yield, phytonutrient content, and soil biological properties as affected by vermicompost to water ratio used for extraction. HortScience 47: 395-402.

Pant, A., T.J.K. Radovich, N.V. Hue, S.T. Talcott, and K.A. Krenek. 2009. Compost extracts influence growth, total carotenoids, phenolics and antioxidant activity in pak choi (Brassica rapa, Chinensis group) grown under two fertilizer regimes. J. Sci. Food Agr. 89:2383-2392.

Radovich, T.J.K. and N.Q. Arancon (eds.). 2012. Tea time in the tropics: A handbook for compost tea production and use. College Trop. Agr. Human Resources, Univ. Hawai'i at Mānoa, Honolulu, HI.

Suthar, S. 2010. Evidence of plant hormone like substances in vermiwash: An ecologically safe option of synthetic chemicals for sustainable farming. Ecol. Eng. 36:1089-1092.

Uchida, R., R. Criley, and F. Rauch. 1979. Substitution of bagasse for peat in growing mediums. Hort. Dig. 52:4-6.

Valenzuela, H.R., T. Goo, R.H. Hamasaki, and T. Radovich. 2001. The effect of bone meal on the yield of jicama, Pachyrbizus erosus, in Oahu Hawai'i. Proc. Florida State Hort. Soc. 113:222-226.

Vivas, A., B. Moreno, S. Garcia-Rodriguez, and E. Benitez. 2009. Assessing the impact of composting and vermicomposting on bacterial community size and structure, and microbial functional diversity of an olive-mill waste. Bioresour. Technol. 100:1319-1326.

Weltzien, H.C. 1990. The use of composted materials for leaf disease suppression in field crops. Monogr. Brit. Crop Protection Council 45:115-120.

Yogi, J., D. Hensley, and J. Hollyer. 1997. Substituting Hawai'i composts for peat in growing media for hibiscus. 10 Aug. 2012. <http://www.ctahr.hawaii. edu/oc/freepubs/pdf/HRN-12.pdfs.

Zaller, J.G. 2007. Vermicompost as a substitute for peat in potting media: effects on germination, biomass allocation, yields and fruit quality of three tomato varieties. Sci. Hort. 112:191-199. 